\title{
Molekulární kardiologie dnes
}

\author{
František Kölbel \\ Interní klinika, Fakultní nemocnice Motol a 2. lékařská fakulta Univerzity Karlovy, \\ Praha, Česká republika
}

Zanedlouho si připomeneme dvacáté výročí publikace, která znamenala začátek nového odvětví klinické kardiologie - kardiologie molekulární. W. McKenna a spolupracovníci identifikovali lokus na chromosomu 14, kde se nacházela první známá mutace genu těžkých řetězců $\beta$-myozinu u nemocného s hypertrofickou kardiomyopatií. ${ }^{(1)}$ Počáteční skromné informace se začaly rozrůstat a kardiologové se začali seznamovat se slovníkem molekulární biologie podobně, jako kdysi naši předchůdci poznávali fyziku v období vzniku elektrofyziologie srdce a biochemii v období poloviny dvacátého století. Podíváme-li se dnes na programy kardiologických kongresů, a prolistujeme-li kterýkoliv moderně píšící kardiologický časopis, je zřejmé, že molekulární kardiologie se pevně usadila mezi staršími, „klasickými“ disciplínami kardiologie. Ostatně toto číslo Cor et Vasa, časopisu Česká kardiologické společnosti, je toho názorným př́íkladem. Potěšitelné je i to, že molekulární kardiologie není dnes disciplínou výlučně molekulárních biologů, ale stala se nástrojem myšlení „klasických“ a „intervenčních“ kardiologů, jak je patrné i z obsahu tohoto, 4. čísla Cor et Vasa. Je radostné, dozvíme-li se o možnostech a výsledcích vlastních vyšetřování polymorfismů genů endotelinu-1 a tumor necrosis faktoru $\alpha$ a $\beta$ (článek L. Špinarové a spol. na str. 127), i o projektu komplexního vyšetřování pacientů s akutním koronárním syndromem, který snese i přísné mezinárodní srovnání( ${ }^{(2)}$ (článek J. Pithy a spol., str. 134), protože zahrnuje i vyšetření polymorfismů tak zajímavého genu, jakým je gen connexinu-37, a dále genu stromelyzinu, inhibitoru aktivátoru plazminogenu 1 a lymfotoxinu- $\alpha$. Přesto se nabízí otázka, zda je to dost, zda se i v této oblasti kardiologie můžeme srovnávat $\mathrm{s}$ jinými odvětvími medicíny $\mathrm{u}$ nás, i se státy s vyspělým zdravotnictvím, kterým jsme důstojnými partnery v řadě parametrů, jakými jsou počty intrakoronárních intervencí, kardiochirurgických výkonů a implantovaných kardiostimulátorů.(3) Není dobré, že nefunguje např. diagnostická možnost detek-

Adresa: prof. MUDr. František Kölbel, DrSc., Interní klinika, FN Motol a 2. LF UK, V úvalu 26, 15018 Praha 5, Česká republika ce mutací genů sarkomerických proteinů u nemocných s hypertrofickou kardiomyopatií (HKM), i když se J. Veselka ve svém úvodníku (str. 123) zmiňuje o důležitosti diagnostiky mutací genu troponinu T, které patrně jako jediné dokážou vyčlenit $z$ nemocných s HKM osoby s malým stupněm srdeční hypertrofie, a přes to s mimořádně špatnou prognózou.

Jistě stojí za úvahu uvažovat, při kterém pracovišti by výhledově mohla začít fungovat jakási analogie Mayo Clinic's Sudden Death Genomics Laboratory. Nabízí se možnost, aby to bylo v Brně při pracovišti, které je schopné diagnostiky genových mutací u nemocných se syndromem dlouhého QT (LQT). Rozšíření této problematiky o diagnostiku HKM by jistě bylo zajímavé a i prakticky nesmírně cenné. A to už vůbec neuvádím problematiku výzkumu kardiomyopatie dilatované, který je značně komplikovaný, ale i velmi perspektivní, protože množství informací a dosud známých poznatků je ve srovnání s kardiomyopatií hypertrofickou podstatně menší. Podobná situace je ve výzkumu genových mutací u fibrilace síní rodinného charakteru, u Brugadova syndromu, Wolfova-Parkinsonova-Whiteova syndromu (WPW), a rady dalších klinických jednotek s arytmiemi. ${ }^{(4)}$

Nerad bych, aby z těchto řádků vznikl dojem, že naše kardiologie nepracuje dosti intenzivně. Chci jen připomenout, jak intenzivně pracují jiná odvětví medicíny, zejména hematoonkologie a výzkum vrozených vad. A také bych rád připomněl možnosti, které poskytuje program EuroGentest, do kterého je již řada našich nekardiologických pracovišt široce zapojena.

\section{LITERATURA}

1. Jarcho JA, McKenna W, Pare PJA, et al. Mapping a gene for familial hypertrophic cardiomyopathy to chromosome 14q1. New Engl J Med 1989;321:1372-8.

2. Anwaruddin S, Askari AT, Topol EJ. Redefining risk in acute coronary syndromes using molecular medicine. J Am Coll Cardiol 2007;49:279-89.

3. Aschermann A. Pohlednice $z$ Prahy a pohled na nás. Cor Vasa 2006;48:8-9.

4. Roberts R. Genomics of Cardiac Arrhythmias. J Am Coll Cardiol 2006;47:9-21. 